\title{
Clinical evaluation of negative-pressure wound therapy in the management of electrical burns
}

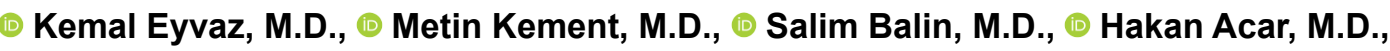

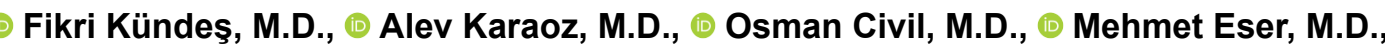

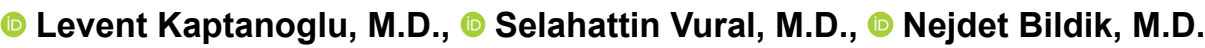

Department of General Surgery, University of Health Sciences, Kartal Dr. Lütfi Kırdar Training and Research Hospital, İstanbul-Turkey

\begin{abstract}
BACKGROUND: In this study, we aimed to evaluate the clinical efficacy and safety of negative-pressure wound therapy (NPWT) in the treatment of the patients with electrical burns.

METHODS: This study was retrospectively performed using a database placed prospectively in the burn center of our hospital. All consecutive patients with electrical burns treated using NPWT at our center between August 2008 and December 2012 were included. The treatment results in our study were grouped as successful or unsuccessful considering the treatment objectives in accordance with therapy indications.
\end{abstract}

RESULTS: In total, 39 patients were included in our study; of them, 36 (92.3\%) were men. The average age was $34.9 \pm 9.8$ years (range, 17-63 years). The majority of the patients in our study $(92.3 \%)$ had been exposed to high voltage electricity. The mean total burned body surface area (TBSA) was $19.3 \pm 9.8$ (range, 4-44). Six patients (I5.4\%) had TBSAs $\geq 30 \%, 31$ (79.5\%) had third degree burns, and 8 (20.5\%) had fourth degree burns. In our study, indications of NPWT included bone and/or tendon exposed deep wounds that are not suitable for early grafting or flap applications owing to the lack of supporting tissue in 27 (69.2\%) patients, graft fixation in 8 (20.5\%) patients, and secondary grafting following graft loss in 4 (10.3\%) patients. The general success rate of NPWT was $90.7 \%$ according to indications and treatment objectives in our study.

CONCLUSION: In the light of our results, NPWT may contribute to the present conventional treatments used in severe electrical burns.

Keywords: Burn; electrical injury; NPWT.

\section{INTRODUCTION}

Since the commencement of electricity in 1849 , it has been one of the most potentially hazardous causes of burn injuries. Approximately $1 \%$ of accidental deaths are caused by an electric injury. Annually, more than 1,000 deaths are reported in the United States due to electric injury, with a mortality rate of $3 \%-5 \% .^{[1,2]}$ Young adult males who were injured in industrial accidents constituted a majority of high-voltage burn patients. ${ }^{[3]}$

Burn wounds are different in many ways from other wounds, and their treatment is generally more challenging. In particu- lar, deep wounds lead to serious problems both in the acute and healing periods. Despite all improved modern treatment methods, burns continue to constitute a serious problem in terms of morbidity as well as mortality. The care of burn wounds and their sequelae necessitate a different kind of expertise. ${ }^{[4]}$

The pathophysiology of electrical injury has been well defined. The tissue damage is commonly severe and progressive owing to vascular injury and prolonged production of thromboxane induced by the electrical current. It is true that high temperature may be produced by the passage of electric current through the tissues, but the nature of electrical

Cite this article as: Eyvaz K, Kement M, Balin S, Acar H, Kündeş F, Karaoz A, et al. Clinical evaluation of negative-pressure wound therapy in the management of electrical burns. Ulus Travma Acil Cerrahi Derg 2018;24:456-461.

Address for correspondence: Metin Kement, M.D.

Sağlık Bilimleri Üniversitesi Kartal Dr. Lütfi Kırdar Eğitim ve Araştırma Hastanesi, İstanbul, Turkey

Tel: +90 216 - 4583000 E-mail: mkement@yahoo.com

Ulus Travma Acil Cerrahi Derg 2018;24(5):456-46I DOI: 10.5505/tjtes.2018.80439 Submitted: 20.05.2017 Accepted: 16.01.2018 Online: 13.09.2018

Copyright 2018 Turkish Association of Trauma and Emergency Surgery 
injury diverges from other thermal injuries because of some specific influences, which are at least partly responsible for the damage. The skin wound of an electrical injury is visibly circumscribed to the area of contact, and this part of the skin is dead. Deep into the skin, the zone of injury extends toward the other point of contact, thereby damaging the deeper tissues. Main vessels procedure good conduction because of their fluid content, consequently resulting in the thrombosis of digital or other main vessels. ${ }^{[5]}$ Local edema that is formed depending on tissue injuries in the electrical burns, significant edema that is initiated by several factors including vasodilation, and increased microvascular permeability extravascular osmotic activity often accompany inflammation. Excessive or prolonged edema and inflammation exacerbate pain and impair wound healing. The clinical challenge becomes management, applying therapeutic intervention only when inflammation and edema worsen. ${ }^{[6]}$

Negative-pressure wound therapy (NPWT) is a non-invasive method wherein controlled, negative pressure is applied on the wound to remove fluid, exudates, and infectious materials, which may promote wound healing and closure. NPWT is an alternative treatment option that has become increasingly widespread in acute and chronic wound treatment. NPWT has been recently performed on burn wounds. ${ }^{[7-9]}$

In the present study, we aimed to evaluate the clinical efficacy and safety of NPWT in the treatment of the patients with electrical burns.

\section{MATERIALS AND METHODS}

\section{Design}

This study was retrospectively performed using a database maintained prospectively in the burn center of our hospital. All consecutive patients with electrical burns who were treated with NPWT in our center between August 2008 and December 2012 were included. Moreover, the patients who died during treatment or somehow could not complete their NPWT because of various reasons were excluded from the study.

\section{Indications of NPWT}

NPWT is performed with three basic indications in our burn unit as follows:

a. To decrease the bacterial load and to accelerate the formation of matrix proteins and granulation tissue in the burns that are not suitable for early grafting or flap applications owing to the lack of a supporting tissue (for example, burns with exposed bone and tendons)

b. To enable graft fixation in areas where graft fixation is difficult

c. To accelerate re-granulation in patients with graft loss following primary grafting. The timing and duration of the application depends on the indication.

\section{NPWT System}

Vacuum-assisted closure system (V.A.C.) ATS Therapy System [Kinetic Concept Inc (KCl), USA] was used as NPWT in our clinic during the study. The system comprises polyurethane and polyvinyl sponges to fill the tissue defects, adhesive semipermeable covers to cover the wound, an apparatus that regulates pressure and provides the connection between the wound and the device (therapeutic regulated accurate care pad), a collection cup, and a device to create negative pressure.

\section{Parameters}

The following data were analyzed in our study: the demographic characteristics of the patients, accompanying comorbidities and The American Society of Anesthesiologists (ASA) scores of the patients, places of the event (house, workplace, or street), type of the electric current (high, low voltage, or arc), localizations and depths (degree) of the burns, percentage of total burned body surface area (TBSA), amputation requirement and their localizations, indications for NPWT, number of NPWT dressing changes, duration of the application, complications encountered during the application, hospitalization time, and outcomes of the therapy.

\section{Evaluation of Outcomes}

The treatment results in our study were grouped as successful or unsuccessful by considering the treatment objectives in accordance with therapy indications. The objectives according to indications can be listed as follows:

a. Ensuring that the wound becomes suitable for grafting or flap application for deep burns that were not previously suitable for grafting or flap application

b. Minimal ( $<10 \%$ of area) or no graft loss in cases where graft fixation is required

c. Ensuring that the wound is suitable for re-grafting in patients who had graft loss following graft application.

\section{RESULTS}

During the study period, 305 patients with electrical burns were treated at our burn center; of them, NPWT was applied to 43 patients (14\%). Four of them were excluded because of mortality before completion of the treatment course. Finally, 39 patients were analyzed in our study; of them, 36 were men

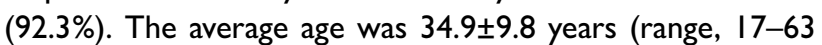
years). The ASA scores and the accompanying morbidities are presented in Table I.

The majority of the patients in our study (92.3\%) were exposed to high voltage current. The mean TBSA was $19.3 \pm 9.8$ (range, 4-44). TBSAs were $\geq 30 \%$ in 6 patients (15.4\%); 31 patients $(79.5 \%)$ had third-degree burns, while 8 of them (20.5\%) had fourth-degree burns. The characteristics of the burns are presented in Table 2. 
Table I. Demographic characteristics and accompanying comorbidities of the patients

\begin{tabular}{lccr}
\hline & $\mathbf{n}$ & $\%$ & Mean \pm SD \\
\hline $\begin{array}{l}\text { Age (years) } \\
\text { Gender (male) }\end{array}$ & 36 & 92.3 & $34.9 \pm 9.8$ \\
$\begin{array}{l}\text { Comorbidities } \\
\quad \text { Diabetes mellitus }\end{array}$ & 2 & 5.1 & \\
$\quad$ Hypertension & 2 & 5.1 & \\
ASA scores & & & \\
$\quad$ ASA I & 0 & 0 & \\
ASA II & 30 & 76.9 \\
ASA III & 6 & 15.4 \\
ASA IV & 3 & 7.7 \\
\hline
\end{tabular}

SD: Standard deviation.

Table 2. Location and characteristics of wounds

\begin{tabular}{lcc}
\hline Parameters & $\mathbf{n}$ & $\%$ \\
\hline $\begin{array}{l}\text { Voltage } \\
\text { High }\end{array}$ & 36 & 92.3 \\
$\quad$ Low & 3 & 7.7 \\
Place of occurrence & & \\
$\quad$ House & 3 & 7.7 \\
$\quad$ Workplace & 33 & 84.6 \\
$\quad$ Street & 3 & 7.7 \\
Burn percentage & & \\
$\quad<15 \%$ & 11 & 28.2 \\
I5\%-30\% & 22 & 56.4 \\
$>30 \%$ & 6 & 15.4 \\
Mean total burned body surface area (\%) & & 19.3 \\
Burn degree & & \\
I-2 & & \\
$3^{\circ}$ & & 0 \\
$4^{\circ}$ & 31 & 79.5 \\
\hline
\end{tabular}

In our study, indications of NPWT included bone and/or tendon exposed deep wounds where granulation could not be achieved using standard dressings in 27 (69.2\%) patients, graft fixation in $8(20.5 \%)$ patients, and acceleration of re-granulation following graft loss in 4 (10.3\%) patients. These indications are shown in Table 3. The numbers of dressings changed and the duration of application in accordance with indications and localizations are presented in Table 4.

The results according to indications and treatment objectives are shown in Table 5. The general success rate of NPWT was $90.7 \%$ in our study. The photographs of a patient taken during their treatment periods are shown in Figure la-d.
Table 3. Indications for negative-pressure wound therapy

\begin{tabular}{lcc}
\hline Indication & n & $\%$ \\
\hline Burn with deep tissue & 27 & 69.2 \\
Lower extremity & 17 & 43.5 \\
Upper extremity & 9 & 23 \\
Other (gluteal region) & I & 2.7 \\
For graft fixation & 8 & 20.5 \\
Lower extremity & 4 & 10 \\
Upper extremity & 3 & 7.6 \\
Other (gluteal region) & I & 2.7 \\
Secondary grafting following graft loss & 4 & 10.3 \\
Lower extremity & 2 & 5.3 \\
Upper extremity & I & 2.7 \\
Other (left inguinal region) & I & 2.7 \\
\hline
\end{tabular}

Table 4. Numbers and duration of negative-pressure wound therapy dressings

\begin{tabular}{lcc}
\hline Indication & $\begin{array}{c}\text { Number of } \\
\text { dressings } \pm \text { SD }\end{array}$ & $\begin{array}{c}\text { Application } \\
\text { duration } \pm \text { SD } \\
\text { (days) }\end{array}$ \\
\hline Burn with deep tissue & $4.2 \pm 1.4$ & $12.2 \pm 5.2$ \\
$\quad$ Lower extremity & $3.6 \pm 1.1$ & $10.7 \pm 4.7$ \\
Upper extremity & $3 \pm 1.3$ & $8 \pm 2.1$ \\
Other (gluteal region) & & \\
For graft fixation & $3.5 \pm 1.7$ & $8.7 \pm 4.1$ \\
$\quad$ Lower extremity & $4 \pm 1.9$ & $12.6 \pm 2.1$ \\
Upper extremity & $3 \pm 1.2$ & $9 \pm 2.4$ \\
Other (gluteal region) & & \\
Secondary grafting following & & $16 \pm 2.5$ \\
graft loss & $5 \pm 2.7$ & $16.3 \pm 2.4$ \\
Lower extremity & $6.1 \pm 3.1$ & $14.5 \pm 3.4$ \\
Upper extremity & $4.2 \pm 1.8$ & \\
Other (left inguinal region) & & \\
\hline SD: Standard deviation. & &
\end{tabular}

\section{DISCUSSION}

Burn management has evolved over several decades through preclinical and clinical research. NPWT was defined by Fleischmann in the 1990s and has become popular. This method, which was initially used in treating the lower extremity fasciotomies, became widespread in terms of indication in time and is being used to treat all types of acute or chronic wounds. [7] The physiological effects of NPWT have been shown in various animal studies. ${ }^{[8,9]}$ Sub atmospheric pressure applied to wounds reportedly increases blood flow, reduces edema, cleans the wound surface, decreases the bacterial load, and accelerates the formation of matrix proteins and granulation 
Table 5. Success rates following negative-pressure wound therapy according to indications

\begin{tabular}{lcc}
\hline Indication & $\mathbf{n}$ & $\%$ \\
\hline Burn with deep tissues ( $\mathrm{n}=27)$ & 24 & 89 \\
$\quad$ Successful & 3 & $1 \mathrm{I}$ \\
$\quad$ Unsuccessful & & \\
For graft fixation ( $\mathrm{n}=8)$ & 7 & 88 \\
$\quad$ Successful & 1 & 12 \\
$\quad$ Unsuccessful & & \\
Secondary grafting following graft loss ( $\mathrm{n}=4)$ & 4 & 100 \\
$\quad$ Successful & 4 & 0 \\
$\quad$ Unsuccessful & 0 & \\
\hline
\end{tabular}

tissue. Besides contributing to the healing of open wounds, NPWT reduces the seroma or hematoma under the graft as well as lowers the separation force between the graft and graft bed, thereby increasing the chance of graft success. ${ }^{[10]}$

Although there is no high-level evidence in literature regarding NPWT in burn wounds, sub-atmospheric pressure is theoretically known to reduce edema that occurs particularly in the stasis zone and increases blood flow in the burn wounds. Therefore, the extending and deepening of the damage may be prevented. Moreover, sub-atmospheric pressure may accelerate the healing of wounds in burn injuries through the aforementioned effects. Since the beginning of the millennium, there are several studies reporting the usage of NPWT on burn wounds. However, most of these publications are case series including few patients. To our knowledge, the only prospective randomized study in this issue is the study presented by Molnar et al., ${ }^{[1]}$ in the II. Wound Healing Association Congress, 2004. In this study, 23 patients who had burn wounds on both hands were evaluated. A dressing was applied using silver sulphadiazine on one hand of the patients, while the other hand was treated with $125 \mathrm{mmHg}$ pressure NPWT. The outcomes measured in the study using Sigma Scan (Systat Software Inc, California, USA) were listed as the level of healing, the volume of the hand, hand usage abilities, grasping, and squeezing forces. In all the parameters, better results were obtained on the hands that were treated with NPWT. The final and definite results of this study have not been published yet. Similarly, Kamolz et al. ${ }^{[12]}$ reported 7 patients in whom the more intense injured hand was treated with controlled applied sub atmospheric pressure the other and less injured hand was conservatively treated using a silver sulphadiazine cream. They observed a massive hyperperfusion in the NPWT treated hand, which could be a reason for the prevention of burn progression. Moreover, they reported a noteworthy amount of fluid removal and a clinically obvious edema reduction compared to the contralateral side. Additionally, Schrank et al. ${ }^{[13]}$ reported some beneficial effects of NPWT in the treatment of hand burns of II cases.

The first study about NPWT excepting hand burns was reported by Nugent et al., ${ }^{[14]}$ who successfully used NPWT on three patients having lower extremity burns with bone exposure. In our opinion, the most interesting publication regarding this method is the study reported by $\mathrm{Si}$ Jack Chong et al., ${ }^{[15]}$ in which NPWT was applied like a "sandwich" according to the authors, such that it coated the bodies of three intensive care patients with extensive burns. This therapy was named as "total body dressing" by the authors. The results were reported to be positive in all patients. Another noteworthy study regarding NPWT in burn wounds is the NPWT following flap application, which was reported by Weinand et al. ${ }^{[16]}$ They applied NPWT following superficial inferior epigastric flap application to a patient having third degree hand and finger burns. In a recent Cochrane Review, Dumville et al. ${ }^{[17]}$ summarized
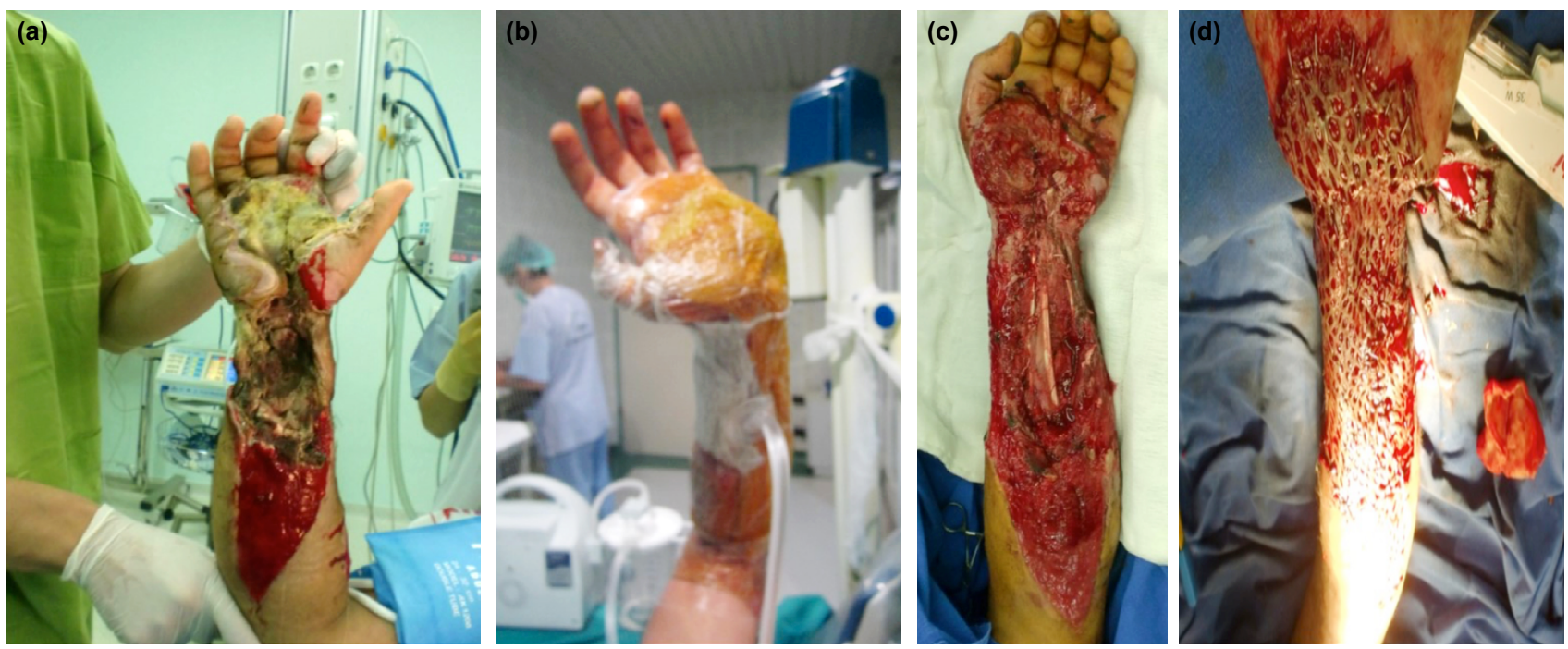

Figure 1. (a-d) Negative-pressure wound therapy (NPWT) treatment course of a patient with fourth degree electrical burn in right arm and hand. (a) Wound at the time of first arrival. (b) NPWT. (c) Post-NPWT tissue granulation. (d) Grafting of wound following NPWT. 
the best available evidence relating to the safety and effectiveness of NPWT in adults with partial-thickness burns. They concluded that their systematic review highlighted the need for good quality research regarding the safety and effectiveness of NPWT in partial thickness burns.

To the best of our knowledge, there is almost no report regarding NPWT for electrical burns. The only publication in this subject is a case presentation reported by Gümüş et al., ${ }^{[18]}$ wherein NPWT was to treat the deep wound on the scalp following an electric shock. Therefore, our study is the most extensive publication on this subject. As a control group was not presented, the treatment results in our study were grouped as successful and unsuccessful by taking into account the treatment objectives according to indications. These objectives were attained in more than $90 \%$ of patients in our study.

Our study had important limitations: it was a retrospective study and there was no control group. Although these limitations pose an obstacle to provide high-level evidence, the clinical outcomes of the NPWT in electrical burns were assessed as successful by our burn center clinicians, who are highly experienced in burn therapies.

\section{Conclusions}

In the light of our results, NPWT may contribute to the present conventional treatments used in severe electrical burns. Nevertheless, our results should be supported by further prospective randomized studies.

\section{Research Involving Human Participants and/or Animals}

The study was approved by the Institutional Research Ethics Committee. All procedures performed in studies involving human participants were in accordance with the ethical standards of the institutional and/or national research committee and with the 1964 Helsinki Declaration and its later amendments or comparable ethical standards.

\section{Informed Consent}

Informed consent was obtained from all participants or their primary relatives of deceased patients.

Conflict of interest: None declared.

\section{REFERENCES}

1. Lee RC. Injury by electrical forces: pathophysiology, manifestations, and therapy. Curr Probl Surg 1997;34:677-764. [CrossRef]
2. Spies C, Trohman RG. Narrative review: Electrocution and life-threatening electrical injuries. Ann Intern Med 2006;145:531-7. [CrossRef]

3. Kurt A, Yıldırım K, Yağmur Ç, Kelahmetoğlu O, Aslan O, Gümüş M, et al. Electrical burns: Highlights from a 5-year retrospective analysis. Ulus Travma Acil Cerrahi Derg 2016;22:278-82.

4. Tiwari VK. Burn wound: How it differs from other wounds? Indian J Plast Surg 2012;45:364-73. [CrossRef]

5. Gajbhiye AS, Meshram MM, Gajaralwar RS, Kathod AP. The management of electrical burn. Indian J Surg 2013;75:278-83. [CrossRef]

6. Rowan MP, Cancio LC, Elster EA, Burmeister DM, Rose LF, Natesan S, et al. Burn wound healing and treatment: review and advancements. Crit Care 2015;19:243. [CrossRef]

7. Fleischmann W, Lang E, Kinzl L. Vacuum assisted wound closure after dermatofasciotomy of the lower extremity [Article in German]. Unfallchirurg 1996;99:283-7.

8. Morykwas MJ, Argenta LC, Shelton-Brown EI, McGuirt W. Vacuumassisted closure: a new method for wound control and treatment: animal studies and basic foundation. Ann Plast Surg 1997;38:553-62. [CrossRef]

9. Moiemen NS, Yarrow J, Kamel D, Kearns D, Mendonca D. Topical negative pressure therapy: does it accelerate neovascularisation within the dermal regeneration template, Integra? A prospective histological in vivo study. Burns 2010;36:764-8. [CrossRef]

10. Thorne $\mathrm{CH}$. Techniques and principles in plastic surgery. In: Thorne $\mathrm{CH}$, Beasley MW, Aston SJ, Bartlett SP, editors. Grabb and Smith's plastic surgery. 6th ed. Philadelphia: Wolters Kluwer Health/Lippincott Williams \& Wilkins; 2007.p. 8.

11. Molnar JA, Heimbach DM, Tredget EE, Hickerson WL, Still JM, Luterman A, et al. Prospective Randomized Controlled Multicenter Trial Applying Subatmospheric Pressure to Acute Hand Burns: An Interim Report. 2nd World Union of Wound Healing Societies' Meeting, Paris France Jun 19-23, 2004.

12. Kamolz LP, Andel H, Haslik W, Winter W, Meissl G, Frey M. Use of subatmospheric pressure therapy to prevent burn wound progression in human: first experiences. Burns 2004;30:253-8. [CrossRef]

13. Schrank C, Mayr M, Overesch M, Molnar J, Henkel V Donnersmarck G, Mühlbauer W, et al. Results of vacuum therapy (v.a.C.) of superficial and deep dermal burns [Article in German]. Zentralbl Chir 2004;129:5961.

14. Nugent N, Lannon D, O'Donnell M. Vacuum-assisted closure - a management option for the burns patient with exposed bone. Burns 2005:31;390-3. [CrossRef]

15. Chong SJ, Liang WH, Tan BK. Use of multiple VAC devices in the management of extensive burns: the total body wrap concept. Burns 2010;36:e127-9. [CrossRef]

16. Weinand C. The Vacuum-Assisted Closure (VAC) device for hastened attachment of a superficial inferior-epigastric flap to third-degree burns on hand and fingers. J Burn Care Res 2009;30:362-5. [CrossRef]

17. Dumville JC, Munson C, Christie J. Negative pressure wound therapy for partial-thickness burns. Cochrane Database Syst Rev 2014;15:CD006215.

18. Gümüş N. Negative Pressure Dressing for the Treatment of High-Voltage Electrical Burn Injury. J Burn Care Res 2010;31:215. [CrossRef] 


\section{ORİIINAL ÇALIŞMA - ÖZET}

\section{Negatif başınçlı yara tedavisinin elektrik yanıklarında klinik olarak değerlendirilmesi \\ Dr. Kemal Eyvaz, Dr. Metin Kement, Dr. Salim Balin, Dr. Hakan Acar, Dr. Fikri Kündeş, Dr. Alev Karaoz, Dr. Osman Civil, Dr. Mehmet Eser, Dr. Levent Kaptanoglu, Dr. Selahattin Vural, Dr. Nejdet Bildik}

Sağıık Bilimleri Üniversitesi, Kartal Dr. Lütfi Kırdar Eğitim ve Araştırma Hastanesi, Genel Cerrahi Kliniği Yanık Ünitesi, İstanbul

AMAÇ: Bu çalışmada, elektrik yanıklarında kullandığımız negatif basınçlı yara tedavisinin (NBYT) klinik etkinliğini ve güvenilirliğini değerlendirmeyi amaçladık.

GEREÇ VE YÖNTEM: Çalışma, hastanemizin yanık merkezinde ileriye yönelik olarak tutulan veri tabanı kullanılarak geriye dönük olarak yapıldı. Ağustos 2008 ile Aralık 2012 tarihleri arasında merkezimizde NBYT uygulanan elektrik yanıklı hastalar ardışık olarak çalışmaya dahil edildi. Çalışmamızdaki tedavi sonuçları, tedavi endikasyonları ve hedefleri dikkate alınarak başarılı veya başarııız olarak değerlendirildi.

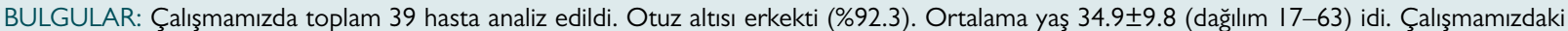

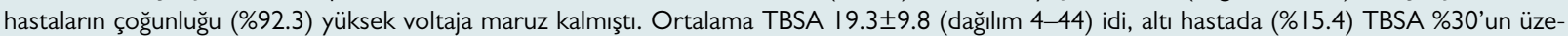
rindeydi. Otuz bir hastada (\%79.5) 3. derece yanık, sekiz hastada (\% 20.5) 4. derece yanık vardı. Çalışmamızda, NBYT endikasyonları; 27 hastada (\%69.2) granülasyonun standart pansumanlar ile elde edilemeyeceği kemik ve/veya tendon içeren erken greftleme ve flap uygulamaları için yeterli destek dokusu olmayan derin yaralanmalar, sekiz hastada (\%20.5) greft fiksasyonu, dört hastada (\%।0.3) ise primer greft kaybını takiben sekonder grefti desteklemek şeklindeydi. Çalışmamızda NBYT'nin endikasyon ve tedavi hedeflerine göre genel başarı oranı \%90.7 olarak tespit edildi.

TARTIŞMA: Sonuçlarımız, NBYT uygulamasının ciddi elektrik yanıklarında kullanılan geleneksel konvansiyonel tedavilere katkıda bulunabileceğini göstermektedir.

Anahtar sözcükler: Elektrik yanığı, negatif basınçlı yara tedavisi; yanık.

Ulus Travma Acil Cerrahi Derg 20|8;24(5):456-46| doi: 10.5505/tjtes.2018.80439 